\title{
THE ROYAL SOCIETY OF EDINBURGH
}

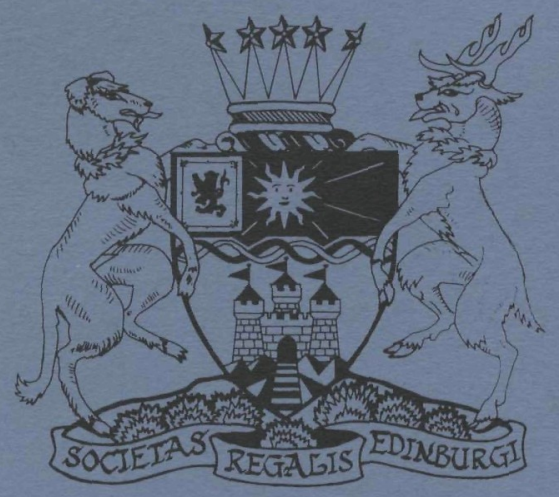

\section{PROCEEDINGS}

Section A (Mathematics)

ISSN 0308-2105

PUBLISHED BY THE ROYAL SOCIETY OF EDINBURGH 22 GEORGE STREET, EDINBURGH, EH2 2 PQ

\section{6}




\section{EDITORIAL BOARD}

\section{Executive Editors}

T. S. BLYTH

University of St Andrews
R. J. KNOPS

Heriot-Watt University

A. M. SINCLAIR

University of Edinburgh
F. M. LESLIE
University of Strathclyde
J. B. MCLEOD
University of Oxford
E. G. REES
University of Edinburgh
D. A. R. WaLlace
University of Stirling
J. R. L. WEBB
University of Glasgow

Heriot-Watt University

F. F. Bonsall

University of Edinburgh

J. W. S. CASSELS

University of Cambridge

M. S. P. EASTHAM

King's College, London

J. R. HubBuck

University of Aberdeen

A. D. SANDS

University of Dundee
C. D. WATERSTON
General Secretary
Royal Society of Edinburgh

W. DUNCAN
Executive Secretary

Royal Society of Edinburgh

\section{Consulting Editors}

H. AMANN

Universität Zürich

M. F. AтtYah

University of Oxford

H. BREZIS

Université de Paris VI

Y. S. CHIN

Academia Sinica, Beijing, China

R. G. Douglas

State University of New York at

Stony Brook, USA

L. C. Evans

University of Maryland, College Park, USA

L. E. FraenKel

University of Sussex

J. K. HALE

Brown University, Providence, RI,

USA

Tosio Kato

University of California, Berkeley,

USA

ROBERT V. KOHN

New York University

J. KURZWEIL

Matematický ústav ĆSAV, Praha,

Czechoslovakia
D. LIVINGSTONE

University of Birmingham

J. E. MARSDEN

University of California, Berkeley, USA

J. MAWHIN

Université Catholique de Louvain

TAKAAKI NISHIDA

Kyoto University, Japan

A. PAZY

The Hebrew University of Jerusalem

DAVID L. RusSELI

University of Wisconsin, Madison, USA

C. A. Stuart

École Polytechnique

Fédérale de Lausanne

L. TARTAR

Centre d'Etudes de Limeil, France

N. S. TRUdINGER

Australian National University,

Canberra, Australia

W. WENDL.AND

Technische Hochschule Darmstadt

A. ZETTL

Northern Illinois University, De Kalb, USA 